\title{
ON THE GEOGRAPHIC DISTRIBUTION OF PARABROTEAS SARSI (MRÁZEK, 1901) (COPEPODA, CALANOIDA).
}

\author{
SOBRE LA DISTRIBUCIÓN GEOGRÁFICA DE PARABROTEAS \\ SARSI (MRÁZEK, 1901) (COPEPODA, CALANOIDA).
}

Patricio De los Ríos ${ }^{\mathrm{I}} \&$ Reinaldo Rivera ${ }^{\mathrm{I}}$

Parabroteas sarsi (Mrázek, 1901) (Copepoda, Calanoida) is a typical species from Southern South American and Sub-Antarctic water bodies (45-68 S, Ruiz \& Bahamonde 1989, Bayly 1992), this species can be found in shallow ponds and few large and deep lakes (Menu-Marque \& Marinone 1986, Janiec 1993, Modenutti et al. 1998, Pugh et al. 2002, De los Ríos 2003', Reissig et al. 2004, Dartnall 2005, De los Ríos \& Contreras 2005, Villalobos 2006, Soto \& De los Ríos 2006, De los Ríos \& Soto 2007). This species has a large body (TL: $5.0-7.0 \mathrm{~mm}$ ), and it is the biggest free living copepod (Araya \& Zúñiga 1985, Villalobos 2006), and it is an active zooplanktivorous predator (Hannsson \& Tranvik 1997, Menu-Marque \& Balseiro 2000, Hannsson \& Tranvik 2003), and it predates on juvenile of cladocerans and copepods (Diéguez \& Balseiro 1998, Modenutti et al. 1998, Vega 1999). The aim of the present note is to study the spatial distribution of the species $P$. sarsi for establishing distribution its in Southern South America and Sub-Antarctic islands.

1 De los Ríos, P. 2003. Efectos de las disponibilidades de recursos energéticos, estructurales y de protección sobre la distribución y abundancia de copépodos y cladóceros zooplanctónicos lacustres chilenos. Tesis de Doctorado, Universidad Austral de Chile, Facultad de Ciencias, Valdivia, Chile. 107 pp.

\section{TAXONOMIC STATUS}

Phylum: Arthropoda

Superclass: Crustacea

Class: Maxillopoda

Subclass: Copepoda

Order: Calanoida

Family: Centropagidae Sars, 1903.

Parabroteas sarsi Mrázek, 1901 (= Parabroteas michaelseni Mrázek, 1901; Limnocalanus sarsi Daday, 1902; Gigantella sarsi Ekman, 1900).

\section{SPACIAL DISTRIBUTION}

\section{ARGENTINA}

Fantasma lagoon (4107' S; $\left.71^{\circ} 27^{\prime} \mathrm{W}\right)$ (Balseiro \& Vega 1994), Juncos lagoon (4004' S $71^{\circ}$ 00' W) (Menu-Marque \& Balseiro 2000), Rivadavia

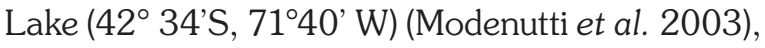
Colhue-Huapi Reservoir (4530' S; 68 46' W) (Menu-Marque \& Marinone 1986), Argentino Lake (50¹5’ 72 33’ W) (Daday 1902), Cabo Vírgenes ponds $\left(52^{\circ} 19^{\prime} \mathrm{S}\right.$; $\left.68^{\circ} 21^{\prime} \mathrm{W}\right)$, Sarmiento ponds

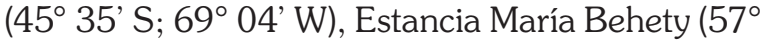
$48^{\prime}$ S, $67^{\circ} 53^{\prime}$ W), Río Chico ponds (5002' S, $68^{\circ}$

I Universidad Católica de Temuco, Facultad de Recursos Naturales, Escuela de Ciencias Ambientales, Casilla 15-D, Temuco, Chile. e-mail (1): prios@uct.cl, (2): patorios@msn.com 
32' W), Tres Lagos ponds ( $\left.49^{\circ} 36^{\prime} \mathrm{S}, 71^{\circ} 30^{\prime} \mathrm{W}\right)$ (Adamowicz et al. 2007).

\section{CHILE}

Los Palos lagoon (45 $15^{\circ} \mathrm{S}, 72^{\circ} 42^{\prime} \mathrm{W}$ ), Riesco lake (4546'S, 72²0'W) (Villalobos 1999²),

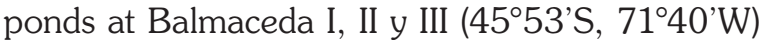
(De los Ríos 2008), Chiguay lagoon (455' S; $71^{\circ}$ 50 ' W) and Elizalde lake (45 $45^{\prime} \mathrm{S}$; $72^{\circ} 25^{\prime} \mathrm{W}$ ) (Araya \& Zúñiga 1985). Permanent ponds: Redonda (51 $\left.01^{\prime} \mathrm{S}, 72^{\circ} 52^{\prime} \mathrm{W}\right)$, Larga (51 $\left.01^{\prime} \mathrm{S}, 72^{\circ} 52^{\prime} \mathrm{W}\right)$, Cisnes (51 $01^{\circ} \mathrm{S}, 72^{\circ} 52^{\prime} \mathrm{W}$ ) (Soto \& De los Ríos

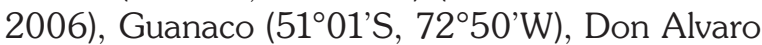
(5101'S, 7252'W) (De los Ríos 2003²). Ephemeral ponds: Vega del Toro (51 $07^{\circ}$ S, $\left.71^{\circ} 40^{\prime} \mathrm{W}\right)$, Kon Aikén (52 $2^{\circ} 50^{\prime} S$, $\left.71^{\circ} 10^{\prime} \mathrm{W}\right)$ (De los Ríos 2005a); Kon Aikén (I-VI) 52 $50^{\prime} \mathrm{S}, 7^{\circ} 50^{\prime} \mathrm{W}$ ), Monte and de los Patos Bravos lagoons (5309' S; 70 57' W) (Mrázek 1901), Porvenir ponds (5317’S, 70¹9’W) (De los Ríos et al. 2008).

\section{ANTARCTIC AND SUB-ANTARCTIC ISLANDS}

Falkland Islands (51 $38^{\prime} \mathrm{S} ; 5^{\circ} 52^{\prime} \mathrm{W}$ ) (Ringuelet 1956), South Georgia Islands (54²10' S; $36^{\circ} 41^{\prime}$ W) (Hannson et al. 1996), South Orkney

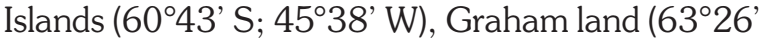

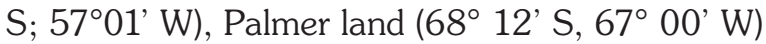
(Pugh et al. 2002), King George Island (62 ${ }^{\circ} 01^{\prime} \mathrm{S}$; $58^{\circ}$ 04' W) (Campos et al. 1978).

In according to the present results, the species $P$. sarsi is located between $41-68^{\circ} \mathrm{S}$, nevertheless, the literature mentioned that this species can be found at $38^{\circ} \mathrm{S}$ in Neuquen Province, Argentina (Ringuelet 1956) and Antarctic continent (Janiec 1993); nevertheless unfortunately both references do not specify details about the records of this species. About the distribution in Chilean continent, it is possible found this species at south of $45^{\circ} \mathrm{S}$ (De los Ríos 2008). In fact this species was not recorded in northern Patagonia $\left(38-41^{\circ} \mathrm{S}\right)$, where it is possible found shallow ponds, small lakes, and large and deep lakes mainly in Araucanía region similar to water bodies of Torres del Paine National Park

Villalobos, L. 1999. Determinación de la capacidad de carga y balance de fósforo y nitrógeno de los lagos Riesco, Los Palos y Laguna Escondida en la XI región. Informe Técnico, Fondo de Investigación Pesquera, Chile, FIP-IT/97-39.
(39 S, De los Ríos, pers. obs.). This result does not agree with other references that described the presence of this species at northern Patagonia (41$45^{\circ} \mathrm{S}$, Villalobos 2006) and central Chile (Brehm 1936). In fact, Brehm (1936) mentioned the record of this species in Verde lagoon $\left(32^{\circ} \mathrm{S}\right.$; Valparaíso region), but in the text, it is mentioned as "ostracod" and this generates confusion and by this reason it is not possible to find this species at central Chilean inland waters.

This species, can coexist with other similar species reported for southern South America, such as $B$. gracilipes, B. michaelseni and B. poopensis and species recorded for southern South America, Antarctica and Sub-Antarctic islands such as $B$. brasiliensis, B. brevicaudata, and B. poppei (MenuMarque et al. 2000, De los Ríos et al. 2008). The habitats of $P$. sarsi are mainly shallow permanent and ephemeral ponds with a low and moderate conductivity (De los Ríos 2005a, De los Ríos \& Contreras 2005, Soto \& De los Ríos 2006). Also, this species can be found in depth layers of few large and deep lakes mainly at $45^{\circ} \mathrm{S}$ (Modenutti et al. 2003, Reissig et al. 2004, De los Ríos \& Soto 2007). Also, the habitats of $P$. sarsi are exposed to high levels of natural ultraviolet radiation due to ozone depletion (Morris et al. 1995, Marinone et al. 2006), and this species has photoprotective strategies such as synthesis of photoprotective substances (Tartarotti et al. 2004), that provide protection against damage of ultraviolet radiation (De los Ríos 2005b, 2007).

\section{ACKNOWLEDGEMENTS}

The authors express their gratitude to the Projects DGI-CDA-01, and for anonymous persons that collaborate in field works.

\section{LITERATURE CITED}

Adamowicz, S., S. Menu-Marque, P. Hebert \& A. Purvis 2007. Molecular systematics and patterns of morphological evolution in the Centropagidae (Copepoda: Calanoida) of Argentina. Biological Journal of the Linnean Society 90: 279-292.

Araya, J. \& L. Zúñiga 1985. Manual taxonómico del zooplancton lacustre de Chile. Boletín 
Informativo Limnológico, Universidad Austral de Chile 8: 1-110.

Balseiro, E.G. \& M.P. Vega 1994. Vulnerability of Daphnia middendorfiana to Parabroteas sarsi predation: the role of the tail spine. Journal of Plankton Research 16: 783- 793.

Bayly, I.A.E. 1992. The non-marine centropagidae (Copepoda, Calanoida) of the world. Guides to the identification of the microinvertebrates of the continental waters of the world. SPB Academic Publishers, Amsterdam 2: 1-30.

Brehm, V. 1936. Mitteilungen von den Forschungsreisen Prof. Rahms. Mitteilung VI. Über die Cladocerenfauna des Titicaca und über einige neue Fundstellen bereits bekannter Copepoden. Zoologischen Anzeigers 114: 157-159.

Campos, H., J. Arenas \& W. Steffen 1978. Antecedentes y observaciones limnológicas en los principales lagos de la Isla Rey Jorge, Shetland del Sur, Antártica. Serie Científica, Instituto Antártico Chileno- INACH 24: 11-19.

Daday, E. 1902. Beiträge zur Kenntniss der Süsswassertiere aus Patagonien gesammelt von Filipo von Sylvestri. Termedzettrajzi Füzetek, Budapest, 25: 436-447.

Dartnall, J.G. 2005. Freshwater invertebrates of subantarctic South Georgia. Journal of $\mathrm{Na}$ tural History 39: 3321-3342.

De los Ríos, P. 2008. A null model for explain crustacean zooplankton species associations in central and southern Patagonian inland waters. Anales Instituto Patagonia (Chile) 36(1): 25-33.

De los Ríos, P., N. Rivera \& M. Galindo 2008. The use of null models to explain crustacean zooplankton associations in shallow water bodies of the Magellan region. Crustaceana 81: 1219-1228.

De los Ríos, P \& D. Soto 2007. Crustacean (Copepoda and Cladocera) zooplankton richness in Chilean Patagonian lakes. Crustaceana 80: 285-296.

De los Ríos, P. 2007. Short term effects of exposition to artificial ultraviolet radiation on Parabroteas sarsi (Copepoda, Calanoida). Biologia, Bratislava, 62: 210 - 213

De los Ríos, P. 2005a. Richness and distribution of zooplanktonic crustacean species in Chilean altiplanic and southern Patagonia ponds. Polish Journal of Environmental Studies 14: 817-822

De los Ríos P. 2005b. Survival of pigmented freshwater zooplancton exponed to artificial ultraviolet radiation ant two levels of dissolved organic carbon. Polish Journal of Ecology 53: 113-116.

De los Ríos, P. \& P. Contreras 2005. Salinity level and occurrence of centropagid copepods (Crustacea, Copepoda, Calanoida) in shallow lakes in Andes mountains and Patagonian plains, Chile. Polish Journal of Ecology 53: $445-450$

Diéguez, M. \& E. Balseiro 1998. Colony size in Conochilus hippocrepis: defensive adaptation to predator size. Hydrobiologia 387/388: 421-425

Ekman, S. 1900. Cladoceren aus Patagonien, gesammelt von der Schwedischen expedition nach Patagonien, 1899. Zoologische Jahrbuecher. Abteilung fuer Systematic Oekologie und Geographie der Tiere 14: 62-84.

Hannsson, L.A., H.J. Dartnall, J.C. Ellis-Evans, H. MacAlister \& L.J. Tranvik 1996. Variations in physical, chemical and biological components in subantarctic lakes of South Georgia. Ecography 19: 393-404.

Hansson, L. \& L. Tranvik 1997. Algal species composition and phosphorus recycling at contrasting grazing pressure: An experimental study in sub-Antarctic lakes with two trophic levels. Freshwater Biology 37:45-53.

Hansson, L. \& L. Tranvik 2003. Food webs in subAntarctic lakes: a stable isotope approach. Polar Biology 26: 783-788

Janiec, K 1993. The freshwater micro- and meiofauna of admiralty bay, King George island, south Shetland islands. Proceedings NIPR Symposyum Polar Biology 6: 133-138

Marinone, M.C., S. Menu-Marque, D. Añón-Suárez, M.C. Diéguez, A.P. Pérez, P. De los Ríos, D. Soto \& H.E. Zagarese 2006. UV radiation as potential driving force for zooplankton community structure in Patagonian lakes. Photochemistry \& Photobiology 82: 962971.

Menu-Marque, S. \& E. Balseiro 2000. Boeckella antiqua n. sp. (Copepoda, Calanoida, Cen- 
tropagidae) from Patagonia. Hydrobiologia 429: $1-7$

Menu-Marque, S. \& M. Marinone 1986. El zooplancton de seis lagos del Chubut (Argentina) y sus probables relaciones con la ictiofauna y algunos factores ambientales. En: Vila I \& E Fagetti (Eds.) 1986. Trabajos presentados al Taller Internacional sobre ecología y manejo de peces en lagos y embalses. Santiago, Chile, 5-10 de noviembre de 1984. COPESCAL Documento Técnico (4): 237 pp.

Menu-Marque, S., J. Morrone \& C. Locascio De Mitrovich 2000. Distributional patterns of the South American species of Boeckella (Copepoda: Centropagidae): a track analysis. Journal of Crustacean Biology 20: 262-272

Modenutti, B., C. Queimaliños, E. Balseiro \& M. Reissig 2003. Impact of different zooplankton structures on the microbial food web of a South Andean oligotrophic lake. Acta Oecologica 24: 289-298.

Modenutti, B.E., E.G. Balseiro, C.P. Queimaliños, D.A. Añón-Suárez, M. Diéguez \& R.J. Albariño 1998. Structure and dynamics of food webs in Andean lakes. Lakes and Reservoirs Research and Management 3: $179-186$.

Morris, D., H. Zagarese, C. Williamson, E. Balseiro, B. Hargreaves, B. Modenutti, R.

Moeller \& C Queimaliños 1995. The attenuation of solar UV radiation in lakes and the role of dissolved organic carbon. Limnology \& Oceanography 40: 1381-1391.

Mrázek, A. 1901. Süsswasser copepoden. Ergebnisse der Hamburger Magalhaelsishen Sammelreise 2: 1-29.
Pugh, P., H. Dartnall \& S. Mcinnes 2002. The nonmarine Crustacea of Antarctica and the Islands of the Southern Ocean: biodiversity and biogeography. Journal of Natural History 36: 1047-1103.

Reissig, M., B. Modenutti, E. Balseiro \& C. Queimaliños 2004. The role of the predaceous copepod Parabroteas sarsi in the pelagic food web of a large deep Andean lake. Hydrobiologia 524: 67-77.

Ringuelet, R.A.1956. Ubicación zoogeográfica de las islas Malvinas. Revista del Museo de la Universidad de la Plata. VI (sección Zoología): 419-464.

Ruiz, R. \& N. Bahamonde 1989. Cladóceros y copépodos límnicos en Chile y su distribución geográfica. Lista sistemática. Publicación Ocasional Museo Nacional de Historia Natural, Santiago de Chile, 45: 1-48 p.

Soto, D. \& P. De los Ríos 2006. Influence of trophic status and conductivity on zooplancton composition in lakes and ponds of Torres del Paine National Park (Chile). Biologia, Bratislava, 61: 541-546.

Tartarotti, B., G. Baffico, P. Temporetti \& H. Zagarese 2004. Mycosporine-like amino acids in planktonic organisms living under different UV exposure conditions in Patagonian lakes. Journal of Plankton Research 26: 753-762.

Vega, M. 1999. Life-Stage differences in the diet of Parabroteas sarsi (Daday) (Copepoda, Calanoida): A field study. Limnologica 29: 186-190

Villalobos, L. 2006. Estado de conocimiento de los crustáceos zooplanctónicos dulceacuícolas de Chile. Gayana 70: 31-39. 